\title{
PUT AND CALL OPTIONS UNDER SECTION 16 OF THE SECURITIES EXCHANGE ACT
}

To counteract the abuses flowing from speculation in a corporation's securities by those in a position to have special knowledge of the corporation's affairs or to manipulate its policies, section 16(b) of the Securities Exchange Act of $1934^{1}$ makes insiders, defined in section 16(a) as officers, directors, or persons owning ten per cent of any one class of a corporation's registered equity securities, ${ }^{2}$ liable to the corporation for any profits realized on the purchase and sale (or sale and purchase) of any "equity securities of ... [ [the] issuer" within any period of six months. ${ }^{3}$ Although section $16(\mathrm{~b})$ is regarded as a "thoroughgoing" statute, intended to "squeeze all possible profits" out of insider speculations, ${ }^{4}$ its applicability to transactions involving puts and calls on the stock of the insider's corporation is unclear. In view of the speculative opportunities provided by these options, ${ }^{\bar{\sigma}}$ insiders may be tempted to turn to them in an attempt to realize speculative profit free from the strictures of section $16(b) .^{6}$

1. 48 Stat. 896 (1934), 15 U.S.C. $\& 78 \mathrm{p}$ (b) (1958). For an exposition of the purposes and operation of $\S 16$, see Loss, SECuRITIES REGULATION 561-98 (1951) [hereinafter citcd as Loss].

2. 48 Stat. 896 (1934), 15 U.S.C. $\& 78 \mathrm{p}$ (a) (1958).

3. Section 16 (b), 48 Stat. 896 (1934), 15 U.S.C. $₹ 78 p$ (b) (1958), provides:

For the purpose of preventing the unfair use of information which may have been obtained by such beneficial owner, director, or officer by reason of his relationship to the issuer, any profit realized by him from any purchase and sale, or any sale and purchase, of any equity security of such issuer . . . within any period of less than six months, unless such security was acquired in good faith in connection with a debt previously contracted, shall inure to and be recoverable by the issuer, irrespective of any intention on the part of such beneficial owner, director, or officer in entering into such transaction of holding the security purchased or of not repurchasing the security sold for a period exceeding six months. Suit to recover such profit may be instituted at law or in equity in any court of competent jurisdiction by the issuer, or by the owner of any security of the issuer in the name and in behalf of the issuer if the issuer shall fail or refuse to bring such suit within sixty day's after request or shall fail diligently to prosecute the same there. after; but no such suit shall be brought more than two years after the date such profit was realized. This subsection shall not be construed to cover any transaction where such beneficial owner was not such both at the time of the purchase and sale, or the sale and purchase, of the security involved, or any transaction or transactions which the Commission by rules and regulations may exempt as not comprehended with the purposes of this subsection.

4. Smolowe v. Delendo Corp., 136 F.2d 231, 239 (2d Cir.), cert. denied, 320 U.S. 751 (1943).

5. See Filer, Understanding Put and Call Optrons 41-42, 53-55, 59-60, 62-64 (1959) [hereinafter cited as Filer] ; LefFler, The Stock Market 363-78 (2d ed. 1957) [hereinafter cited as LEFFLER].

6. The staff of the Division of Trading and Exchanges of the Securities and Exchange Commission is currently working on a factual study of puts and calls for the in- 
A put is a negotiable option contract giving the bearer the right to deliver to the writer of the contract a certain number of shares of a particular stock at a fixed price on or before a certain date. ${ }^{\top} \mathrm{A}$ call is a similar option giving the bearer the right to buy securities. ${ }^{8}$ Both contracts are originally offered for a "premium," determined by the price of the stock, its past and projected fluctuations on the market, the length of time before the option expires, and the original difference, or "spread," between the stock's option and market prices. ${ }^{9}$ Thereafter, the options themselves gain or lose in value as the spread varies. Since the premium is small in relation to the underlying securities' value, and market fluctuations are fully reflected in the value of the option, puts and calls are extremely attractive speculative devices. ${ }^{10}$ Put and call

formation of the Commission in determining what, if any, action it should take with regard to them. Letter From Phillip A. Loomis, Director, Division of Trading and Exchanges, SEC, to the Yale Law Journal, March 15, 1960, on file in Yale Law Library. It is believed, however, that their current use by insiders is not widespread. Letter From Harold V. Lese, Chief, Branch of Interpretation and Review, SEC, to the Vale Lat" Journal, Oct. 13, 1959, on file in Yale Law Library.

7. FIIER 20-21.

8. Id. at 24-25. Puts and calls are normally issued to cover blocks of 100 shares, id. at 18-19, and are written for periods of 30 days, 60 days, 90 days, six months and 10 days, and occasionally for as long as a year, id. at 19. In addition, put and call dealers offer "special" options which have been purchased by the dealer himself in the hopes that they can be resold to customers. In terms of the spread, exercise price, and premium, see text at note 9 infra, these options are slightly more advantageous than "new" options, since the market movement which is necessary before the option will show a net paperprofit is smaller than for new options. On the other hand, the risk that this market movement will not occur is increased, since the option begins to run on the day the maler delivers it to the dealer, not on the day the dealer sells it to a customer. Thus, an option which originally ran for ninety days may have only eighty days remaining when the customer receives it. See id. at 31-34.

Other options, which are combinations of puts and calls, are nut treated as such in this Comment. A "straddle" is a combination of a put and a call in which both components are exercisable at the same price. Id. at 34. A "spread" resembles a straddle, but its put half.is exercisable at a price below current market, while its call half is exercisable at a price above current market. Ibid. A "strip" is a straddle with an extra put, id. at 106, and a "strap" is a straddle with an extra call, id. at 107.

9. See LEFFLER 369. Two types of options are prevalent today: the "wide-price" option, and options written "at the market." In the first a spread exists between exercise price and market price on the day the option is issued; on a call the exercise price would be higher than the market, and for a put it would be lower. In the "market" option the exercise price is identical with the market price on the issue date. The premium charged for a market option is always higher, since the risk for the optiunmaker is greater. Sce id. at 367-70.

10. "One consequence of trading against an option is that it greatly magnifies the opportunities for profit in relation to the amount of the investment ...." SEC Sec. Exch. Act Release No. 4509 , Oct. 30, 1950 , p. 5. In a falling market, a put on 100 shares of any stock will increase $\$ 100$ in value with every point that the market drops, the only variable as far as profits are concerned being the amount of the premium. For example, a person may acquire a put option giving him the right to sell 100 shares of the stuck of $A$ corporation to the writer of the put at $\$ 50$ per share, paying a premium of $\$ 350$ for 
transactions which can lead to the realization of speculative profit range from the simple purchase and sale of unexercised puts or calls to complex transactions in which acquisition and exercise of the option are combined with purchases and sales of the underlying stock. The purchase of an option may be followed by its exercise and the subsequent repurchase or sale of the stock involved. Or, an option may be used to immunize paper profits from future market fluctuations. For example, the purchase of stock at a low price may be followed by the acquisition of a put when the market rises. During the life of the put, the speculator's profit would be protected by his power of exercise, while he could benefit by any further upward movements by allowing the put to expire and selling at the market price. Similar "profit freezing" can be accomplished by selling stock during the life of a call acquired at a lower price, acquiring a call at a low price following a sale of stock in a higher market, or purchasing stock while holding a put exercisable at a higher price. ${ }^{11}$ This Comment will analyze various transactions involving puts and calls in order to determine their proper treatment under section 16.

\section{Trading in Unexercised Puts and Calls}

As a method of insider speculation, purchase and sale of unexercised puts and calls is no different from purchase and sale of the stock itself. Assume that $A$, an insider, learns that his corporation has secured a profitable government contract. Expecting the market to rise, he purchases stock at fifty dollars before the information is made public. The expected market rise occurs, and within three months the stock is selling at seventy dollars. A sale of the appreciated stock at this point would clearly subject $A$ to section 16(b) liability. But assume that instead of purchasing stock, $A$ acquired a call, selling it unexercised after its value had appreciated by the same amount as a result of the same market rise. ${ }^{12}$ Similarly, had $A$ 's inside information led him to expect a market decline, he might have sold his stock, repurchasing it at a lower price; the same effect could be obtained by an acquisition and disposition of a put. The functional equivalence of the described option transactions to those involving the stock itself suggests that liability should attach to the former as well as the latter.

Section 9(b), which gives the Securities and Exchange Commission power to regulate transactions in which puts, calls, and other options are acquired

the option. At this time he need own no stock at all. Should the market drop to $\$ 30$, he may buy 100 shares for $\$ 3,000$ and "put" them to the writer of the put for $\$ 5,000$, leaving a net profit of $\$ 1,650$ minus brokerage fees, on a $\$ 350$ investment. Calls provide similar opportunities in a rising market. See FILER 41-43. For purposes of computing profits throughout this Comment, taxes and brokerages fees will be disregarded.

11. For a detailed discussion of "profit-freezing" transactions see text at notes 61.84 infra.

12. A put and call broker, for example, will repurchase an option which shows a paper-profit for a price equal to the spread between the net option price and the prevailing market price, less two brokerage fees and taxes. FILER 38. 
in connection with dealings in stock, ${ }^{13}$ is the only specific reference to puts and calls in the act; but section 9's legislative history, demonstrating congressional hostility to options used in market manipulation, makes it unlikely that Congress intended to exempt insider trading in unexercised puts and calls from the operation of the statute. ${ }^{14}$ Moreover, section 16 (b)'s approach reveals a general intent to prevent insider short-swing speculation 10 which, as viewed by Congress, involved two evils. First, outsiders trading in the market are prejudiced if they are forced to deal with persons whose peculiar position gives them access to information unavailable to others. ${ }^{10}$ More important, speculation by insiders, who normally are in a position to dictate corporate decisions, was thought to be inconsistent with their position as fiduciaries for outside shareholders. ${ }^{17}$ Thus, even if it be argued that the writers of puts and calls, themselves highly sophisticated investors, ${ }^{18}$ require no congressional protection

13. 48 Stat. 889 (1934), 15 U.S.C. § 78i(b) (1958).

14. One of Congress' chief concerns was the use of the options as an aid to market manipulation by stock pools, see S. REP. No. 792, 73d Cong., 2d Sess. 9 (1934), the members of which would take an option at a low price and exercise it after pool operations had driven the market upwards, see LEFFLER 338-47 (describing pool operations). Thus pool operations were prohibited by $\S 9$ (a), 48 Stat. 889 (1934), 15 U.S.C. § 78i(a) (1958). See Frey, Federal Regulation of the Over-the-Cosmier Securities Marled, 100 U. PA. L. REv. 1, 22 (1957). Indeed, although the less stringent provisions of $\$ 9$ were ultimately adopted, see H.R. REP. No. 1383, 73d Cong., 2d Sess. 21 (1934); Loss 306, Herbert Filer, representing the Put and Call Brokers and Dealers Assaciation, was obliged to defend the usefulness and economic value of the put and call business, so that all options would not be blanketly prohibited, FILER 10, 77-78.

15. The near impossibility of proving the intent to abuse inside information led to the establishment of an admittedly arbitrary "objective measure of proof" whereby any transaction carried out within six months gives rise to a conclusive presumption that insiders have used inside information unfairly. Smolowe v. Delendo, 136 F.2d 231, 235 (2d Cir.), cert. denied, 320 U.S. 751 (1943); see Loss 564; Hardee, Stock Options and the "Insider Trading" Provisions of the Securities Exchange Act, 65 Hanv. L. Rev. 997, 998, 1007 (1952).

16. S. REP. No. 1455, 73d Cong., 2d Sess. 55 (1934).

17. Ibid. Congress found numerous cases of market manipulation by speculating insiders, and discovered at least one instance in which a corporation had followed an unsound dividend policy during a period when one of its insiders was speculating actively. See S. REp. No. 792, 73d Cong., 2d Sess. 9 (1934).

18. Options are usually written by wealthy stockholders, funds, trusts, and insurance companies. Optionmakers ordinarily have large, varied holdings in securities, and put-andcall dealers are reported hesitant to deal with individuals with less than $\$ 50,000$ capital. The primary object of an optionmaker in writing puts and calls on his securities is to supplement the income on his investment. If a put or a call he has issued expires unexercised, the premium may be thought of as additional income on the security In order to make his option selling profitable, the optionmaker must deal in averages, hoping that his informed guesses as to market trends will be right more often than not. If the market moves against him, the maker will either be forced to take securities at a price higher than the prevailing market or, if a call is exercised, sell securities for a price lower than the market. Thus he must normally sell many options in order that the premiums received compensate for his wrong guesses. See FILER 96-99; LEFrLER 372-73. 
from those with advance information, the possibility that these very evils may be perpetrated through insider trading in unexercised puts and calls militates against excluding these options from $16(\mathrm{~b})$.

The SEC's only specific pronouncement on puts and calls is ambiguous. Rule 16a-1(h) provides that, for purposes of the reporting requirements of section $16(\mathrm{a})$, "the acquisition or disposition of any transferable option, put, call, spread or straddle shall be deemed such a change in the beneficial ownership of the security to which such privilege relates" as to require reporting of the acquisition and disposition of puts and calls on securities of the insider's corporation. ${ }^{19}$ Since one purpose of section $16(\mathrm{a})$ is to publicize transactions which give rise to section 16 (b) liability, ${ }^{20}$ rule $16 a-1$ (h) may indicate Commission belief that puts and calls are contemplated by $16(\mathrm{~b})$. On the other hand, a frequently mentioned policy behind section $16(\mathrm{a})$ is that disclosure alone will discourage many transactions regardless of 16 (b) liability, ${ }^{21}$ and a later SEC release pointed out that not all transactions required to be reported lead to $16(\mathrm{~b})$ liability. ${ }^{22}$ Accordingly, rule $16 \mathrm{a}-1 \mathrm{~h}$ ) should be viewed as only a clarification of the reporting requirements and not as an indication that puts and calls are or are not within the purview of section $16(\mathrm{~b})$.

Since the purposes of that section would be best served by including puts and calls, and since neither Congress nor the SEC has evinced any clear intention of excluding them, the principal problem facing a court is the semantic one of fitting these options into the statutory definition of "equity security." "Equity security" is defined in section 3(a) (11) as "any stock, or similar security; or any security convertible ... into such a security, or carrying any warrant or right to subscribe to or purchase such a security ; or any such warrant or right . ..." and the SEC is empowered to define other securities as equity securities when necessary to serve the purposes of the act.23 But, as indicated above, the Commission has been silent on this topic; although rule 16a$1(h)$ 's declaration that acquisition of options "shall be deemed . . . a change in beneficial ownership" may suggest that the SEC hesitated to classify puts and calls as equity securities, the Commission, had it wished to exclude puts and calls from $16(\mathrm{~b})$, would have done so under the express power granted to it by that section to exempt transactions "not comprehended" by the stati" tory purpose, ${ }^{24}$ rather than by negative implication.

19. 17 C.F.R. $\$ 240.16 a-1$ (h) (Supp. 1959). Exercise of these options must also be reported. Ibid.

20. See Loss 564-65 ; Yourd, Trading in Securities By Directors, Officers and Stockholders: Section 16 of the Securrities Exchange Act, 38 Mrch. L. Rev. 133, 139 (1939).

21. See, e.g., Loss 77-82. "Because it is difficult to draw a clear line as a matter of law between truly inside information and information generally known by the better-informed investors, the most potent weapon against the abuse of inside information is full and prompt publicity." H.R. Rep. No. 1383, 73d Cong., 2d Sess. 13 (1934). It has been suggested, however, that disclosure alone is not an effective deterrent. See Loss 78-81.

22. SEC Sec. Act Release No. 4801, Feb. 20, 1953, p. 2.

23. 48 Stat. 884 (1934), 15 U.S.C. \& 78c(a) (11) (1958).

24. Section 16(b), 48 Stat. 896 (1934), 15 U.S.C. $\$ 78 p$ (b) (1958). 
Calls can easily be classified as equity securities under the language "warrants or similar right." But the various rights denominated "equity securities" in section 3(a) (11) are rights to purchase or acquire, rather than to dispose of "any stock or similar security." Thus, puts cannot be brought within this language, although the fact that they can be used for the same speculative purpose as calls suggests that they should be given similar treatment. A court could accomplish this result by including puts in the phrase "stock or similar security." It is generally conceded that puts, as well as calls, are "securities" for purposes of the act. ${ }^{25}$ Furthermore, the term "equity security" (as differentiated from "security") is used only in section 16. This seems to indicate that Congress intended the term to cover those securities which, because their market prices are extremely sensitive to changes in corporate fortunes, provide insiders with the opportunity to reap short-swing profits by using them for speculation. In a functional sense, then, puts can be viewed as "similar" to stock, and thus equity securities under section $3(a)$ (11).20

The question remains, however, whether such a broad reading of the statute in the absence of an exercise of the SEC's definitional power might be considered an assumption by a court of powers primarily delegated to the Commission. But no particular administrative expertise is required to find that puts provide the speculative opportunities which Congress sought to control. Moreover, court action here would not render the Commission's definitional power meaningless. Should the Commission disagree, it retains the power under section 16(b) to exclude puts as transactions "not comprehended within the purpose" of the act. Therefore, a court should not hesitate to bring puts within section 16 only because the Commission has not spoken on the matter. On the other hand, the possibility that semantic difficulties may lead some courts to adopt a narrow definition of "equity security," allowing insiders to retain the profits from speculation in puts, suggests that reliance on judicial action would be misplaced and that the SEC should exercise its statutory power and bring puts within $3(\mathrm{a})(11)$.

A second argument which may be advanced to avoid insider liability on shortswing transactions in unexercised puts and calls turns upon the meaning of the phrase "any equity security of such issuer" in section $16(b)$; if the italicized phrase means issued "by the corporation," puts and calls, issued by third parties, are not covered. "Of the issuer" is introduced in section 16(a) to

25. See Loss 306 . The Uniform Commercial Code once explicitly considered puts as securities. UnIForar Consarercial CODE § \&-102 (Proposed Final Draft 1950). Later drafts fail to mention puts. But the latest draft defines a security as "an instrument which is issued in bearer or registered form ... of a type commonly dealt in upon securities exchanges or markets or commonly recognized in any area in which it is issued or dealt in as a medium for investment." UnIForar COArarercial CODE \& 8-102. And the comment following regards the term "security" as "anything which securities markets ... . are likely: to regard as suitable for trading." UNIForar CoMrarercial CODE \$ \&-102, comment at 530-31.

26. Compare Cook \& Feldman, Insider Trading Under the Securities Exchange Act, 66 HaRv. L. Rev. 385, 394-95 (1953). 
identify which officers, directors, and stockholders are covered-they must be of a corporation which has issued any registered security. ${ }^{27}$ Hence, since "such issuer" in the succeeding subsection refers to "issuer of any registered security," not necessarily of the particular security involved in a section 16 transaction, the word "issuer" in 16(b) carries no meaning beyond "corporation included within section 16." Therefore, it is at least as reasonable to read "of" as meaning "relating to," one of its commonly accepted senses, ${ }^{28}$ as to define it as "issued by." The "relating to" construction eliminates from section 16 a possible distinction between securities issued by the corporation and paper issued by others which pertains to and derives its value from those securities, and thus serves the plan of the statute, for in order for the dangers of insider speculation to be present, it is not necessary that a particular equity security be issued by the insider's corporation, but only that the security be so related to the corporation that its market price will fluctuate with changes in corporate fortunes.

Hence, insider trading in unexercised puts and calls would seem to belong within the bounds of section 16(b). Even assuming that conclusion, however, an argument might be made for imposing additional restrictions upon such trading, either by extending the 16(b) holding period for unexercised options or by prohibiting completely their transfer by insiders. A decision to make long-term (more than six months) profits from trading in unexercised puts and calls recoverable would be based on three premises. First, it may be believed that possession of unexercised options furnishes an extremely favorable vantage point from which to watch the market, and therefore a greater likelihood of abuse from inside information than does possession of stock. Second, options, which may be acquired with a relatively small amount of capital, may increase the temptation for an insider to indulge in market manipulation. Third would come the argument that since, under SEC rule $16 \mathrm{~b}-6$ and its case law, long-term increment in the value of an option to purchase is recoverable when, within a separate six-month period, the option is exercised and the stock then sold, ${ }^{20}$ long-term appreciation in an option's value should be recoverable when the option is transferred as well.

Trading in negotiable options should, however, be treated identically with trading in other equity securities. The recoverability of an option's long-term

27. 48 Stat. 896 (1934), 15 U.S.C. \& 78p(a) (1958):

Every person who is directly or indirectly the beneficial owner of more than 10 per centum of any class of any equity security (other than an exempted security) which is registered on a national securities exchange, or who is a director or an officer of the issuer of such security, shall file, at the time of the registration of such security or within ten days after he becomes such beneficial owner, director, or officer, a statement with the exchange ... of the amount of all equity securities of such issuer of which he is the beneficial owner. . . .

(Emphasis added.)

28. Merriam-Webster New International Dictionary 1689 (2d ed. 1957).

29. See text at notes $44-46$ infra. 
increment in value under rule $16 \mathrm{~b}-6$ is not a persuasive argument to the contrary, since, as will be demonstrated, that rule is improper as applied to freely transferable options, and the inconsistency between allowing long-term profits in options to be recovered when the option is exercised and refusing recovery when the option is transferred should be resolved in favor of the latter route. ${ }^{30}$ Further, from the standpoint of the misuse of insider information, it can be demonstrated that investment in puts or calls is economically no more attractive than investment in stock. The buyer of a call, for example, is in effect betting that the market price of the stock will rise, within a certain period, more than the prevailing market estimate. Unlike the buyer of stock, who can minimize his losses by selling if the stock fails to appreciate, the holder of a call stands to lose his entire investment (the amount of the premium) unless the rise he expects occurs. Because of the risk involved, calls must offer a return in proportion to the odds against success. Thus, the greater volatility of puts and calls reflects the fact that the purchase of an option is a bet against greater odds than a purchase of stock. The insider's confidential knowledge can, of course, give him an advantage, whether he buys stock or buys an option. But the assumption of $16(\mathrm{~b})$ that within the six-month holding period various unpredictable factors will nullify this advantage seems as applicable to trading in unexercised options as to trading in stock. If the insider in fact has no advance information, a call, for example, is an extremely unattractive bet. Its cost will be set to attract investors willing to wager that the price of the underlying security will rise sufficiently at some time during the life of the call to make risking the premium worthwhile. If $16(\mathrm{~b})$ is applied to calls, without more, the insider is forced to bet that his stock will attain (or maintain) a high level after the six-month period. Thus the odds against him are greater than those against the noninsider, although his return will be the same. Accordingly, it would seem extremely unlikely that an insider would buy one in order to obtain a favorable position from which to watch the market. ${ }^{31}$ Finally, although the possibility of using puts and calls as a low-investment prelude to market manipulation might theoretically justify a differentiation between options and other equity securities, it is doubtful whether such a differentiation is a practical necessity. Manipulative schemes may in fact be effectively deterred by other sections of the act, ${ }^{32}$ and corporate management may now subscribe to higher ethical standards than those which the draftsmen of the 1934 act sought to correct.

30. See text at notes $43-51$ infra.

31. Nonetheless, puts and calls may be more attractive speculative devices than other securities requiring more substantial investment. It is an observable phenomenon that people are more willing to risk one dollar at 100 to 1 odds with a 50 to 1 payof than one hundred dollars at 3 to 2 odds with a 3 to 2 return. See Freidman \& Savage, The Utility Analysis of Choices Involving Risk, in Readings in PeICE Tyeozy 57 (Stigler \& Boulding ed. 1953).

32. Section 9(a), 48 Stat. 889 (1934), 15 U.S.C. § 78i(a) (1958), prohibits manipulation of market prices through the use of stock pools; $\$ 10,48$ Stat. 891 (1934), 15 U.S.C. $\S 78 \mathrm{j}$ (1958), prohibits fraud in the purchase or sale of securities. 
Transactions Involving Both Puts and Calls and the Underlying STOCK

\section{Exercising a Put or Call as Step One in a Short-Szeing Transaction in Stock}

\section{Option Held for Less Than Si.x Months}

When the exercise of a call is followed or preceded by a sale of the underlying stock within six months-or when the exercise of a put is similarly combined with a purchase of the underlying stock-a court would undoubtedly find liability. ${ }^{33}$ It is well settled that the acquisition of stock through the exercise of an option is a "purchase" within the meaning of section $16(\mathrm{~b}) ;$ the exercise of a put, or option to sell, is a sale as that term is generally used and would be so treated under section 16(b). Finding liability here has been criticized on the theory that no fundamental difference exists between, for example, the acquisition of an option to buy on January 1 and its disposition unexercised on July 2-a transaction free from liability-and the sale on July 2 of stock acquired by exercising the same option in March. This criticism views the profit in the second transaction as the result of a long-term increment in the stock's value between acquisition and exercise of the option, and therefore beyond the reach of section $16(\mathrm{~b}) .^{35}$ But when the option in question is a put, call, or other option with a fixed termination date, its exercise may properly be viewed as the beginning of a new six-month period. Section 16 (b)'s requirement of a substantial holding period seems predicated, at lenst in part, on a theory that inside information is likely to become stale within six months, since market fluctuations, especially those which are artificially stimulated, are generally of short duration. Thus any transaction which provides an insider with the opportunity to profit from new information should start a new six-month period..$^{36}$ The holder of a call, for example, must ultimately decide whether to exercise it, sell it unexercised, or allow it to expire, and, assuming favorable market movements during the life of the option, he could realize profit by selling it unexercised. A decision to exercise it instead may be attributed either to a desire to take advantage of market fluctuations which fresh inside information indicates will take place after the expiration date of

33. Cf. Steinberg v. Sharpe, 95 F. Supp. 32 (S.D.N.Y. 1950), aff'd per curiam, 190 F.2d 82 (2d Cir. 1951).

34. Shaw v. Dreyfus, 172 F.2d 140, 142 (2d Cir.) (dictum), cert. denicd, 337 U.S. 907 (1949); see Greene v. Dietz, 247 F.2d 689 (2d Cir. 1957) (option issucd purstaunt to employee compensation plan) ; Steinberg v. Sharpe, 95 F. Supp. 32 (S.D.N.Y. 1950), aff'd per curian, 190 F.2d 82 (2d Cir. 1951) (stock options); cf. Park \& Tilford, Inc. v. Schulte, 160 F.2d 984, 987 (2d Cir.), cert. denied, 332 U.S. 761 (1947) (conversion of preferred stock into common). But cf. Ferraiolo v. Newman, 259 F.2d 342 (6th Cir. 1958) ("involuntary" conversion of preferred stock held not a purchase).

35. Hardee, Stock Options and the "Insider Trading" Provisions of the Sccuritics Exchange Act, 65 HARv. L. Rev. 997, 1007 (1952).

36. Cf. Ferraiolo v. Newman, 259 F.2d 342, 345 n.3 (6th Cir. 1958). Sce also SEC Exch. Act Release No. 4509, Oct. 30, 1950. 
the option, ${ }^{37}$ or to a desire to make a long-range investment in the corporation. Subsequent sale of the stock within six months eliminates any possibility of the long-range investment motive, and section $16(\mathrm{~b})$ liability should attach. Similar considerations govern when a put, rather than a call, is involved.

Once liability is found, the court must calculate recoverable profit. The simplest approach would be to hold the insider liable for the difference between option price and the ultimate sale or repurchase price, less, of course, the option's cost. ${ }^{38}$ When an option is held less than six months before exercise, this approach would be proper. Since exercise of an option ends its life and destroys its independent value, exercise of a call may be regarded equivalent to its sale coupled with a simultaneous purchase of stock; exercise of a put as equivalent to its sale coupled with a sale of stock. Thus, for example, exercising a call after holding it less than six months and selling the underlying stock thus acquired within six months of exercise may properly be regarded as two short-swing transactions-one in the option, the other in the stock. Therefore, measuring recovery by the difference between option price and ultimate sale price does not involve, as has been suggested, the inconsistent use of a short holding period for the purpose of finding liability, and a longer accrual period for the purpose of measuring profit..$^{30}$ Rather, it is simply the recovery of the entire amount of speculative profit on two short-swing transactions.

Regarding exercise of an option as equivalent to a sale thereof raises another question, however; should liability attach when acquisition and exercise of an option occur within six months, even if the underlying stock is immobile thereafter? Ownership of an option obviously enables an insider to enter the market at a more favorable price than those who purchase or sell stock at market price on the date he exercises. When this advantage is attributable to a short-term market fluctuation, it would not be contrary to the purpose of $16(b)$ to treat insider acquisition and exercise as a purchase-sale combination leading to recovery of the difference between option price and market price at exercise date, less the option's cost. But the longer an insider holds the stock he acquires (or refrains from repurchasing stock he has held) the less likely it becomes that the original acquisition ("purchase") and exercise ("sale") of the option was motivated by a desire to realize "short-swing" profits. Although motive is irrelevant once a purchase-sale combination has been found, ${ }^{40}$ it may be crucial in determining whether a given transaction constitutes a "purchase" or "sale." It It should be noted, however, that allow-

37. See Comment, 59 YALE L.J. 510, 524-26 (1950).

38. See SEC Exch. Act Release No. 4509, Oct. 30, 1950, p. 2

39. Hardee, supra note 35 , at 1006.

40. "[Short-swing profits] shall inure to and be recoverable by the issuer, irrespective of any intention on the part of [the insider] ... of holding the security purchased or of not repurchasing the security sold for a period exceeding six months." Section $16(\mathrm{~b})$, is Stat. 896 (1934), 15 U.S.C. \& 78p(b) (1958).

41. Cf. Truncale v. Blumberg, 80 F. Supp. 387, 392 (S.D.N.Y. 1948). ("By the ap- 
ing recovery in this situation would not penalize the insider, but would only nullify any advantage he gained as the result of his short-term holding of the option. If it is held that acquisition and exercise of an option within six months constitutes a 16 (b) purchase-sale combination, a remaining problem is determining when, if at all, recoverable profits were "realized," as required by section $16(\mathrm{~b})$. In the case of a put transaction, the insider will receive cash when he exercises. Little conceptual or practical difficulty would arise if the proceeds attributable to the "sale" of the option were deemed immediately "realized," 4 " and the insider thereafter treated as if he had sold stock at the market price prevailing on exercise date, with further liability accruing only if, within the ensuing six months, he engaged in further market operation equivalent to a "purchase." The exercise of a call, on the other hand, involves a substantial investment in the underlying stock and the receipt of stock only. And the insider will remain subject to the risk of the market as the price of his stock fluctuates. Thus it would seem that no profit from the "sale" of the call could be "realized" until he resold the stock. At that time he could be forced to surrender profits equivalent to the monetary advantage he gained as a result of acquiring the stock at call price within six months of acquiring the call.

\section{Options Held for Six Months or More}

Profits on a short-swing in stock commenced by exercise of an option should be measured differently when the put or call involved in the transaction is held for more than six months prior to exercise. ${ }^{43}$ After holding a put or call for six months, an insider could sell the option unexercised, retaining the resulting long-swing profits without liability. In the case of a call, for example, werc the proceeds of such sale, together with additional cash, used to purchase stock, the cost basis of the stock for the purpose of determining profits on a subsequent short-swing sale would be the total cash layout, that is, actual cost of stock at market price, and the insider would retain the profits resulting from the long-swing increment in the call's value. To illustrate, assume that an insider acquires a call on January 1 which gives him the right to buy stock at ten dollars. Assume further that he exercises the call on August 1, when the stock's market price is twenty dollars, and sells the stock at thirty dollars on September 1. Had he sold, rather than exercised, the call on August 1, he would have earned ten dollars profit free from liability, since that profit would have been the result of long-swing appreciation of the call. Similarly, the only short-swing profit stemming from exercise and ultimate sale is ten dollars, the

plication of familiar principles the transaction falls into one category or another depending upon the intention of the parties"; gift of warrants held not a "sale").

42. For example, if a put is acquired to sell stock at $\$ 50$, and subsequently exercised while the prevailing market is at $\$ 40, \$ 10$ of the $\$ 50$ received for the stock may be attributed to the disposition of the option, since only $\$ 40$ would have been realized on the stock had it been sold in the open market.

43. See Cook \& Feldman, Insider Trading Under the Securities Exchange Act, 66 HaRv. L. Rev. 612, 623-24 (1953). 
difference between thirty dollars (eventual sale price) and twenty dollars (option price plus market value of option at date of exercise, which would be equal to market price of stock at date of exercise), while the recovery of the difference between thirty dollars (eventual sale price) and ten dollars (option price) would include ten dollars of long-swing profit. Therefore, a rule may be stated: when stock is acquired through exercise of a freely transferable option such as a call, which has been held for over six months, the basis of the stock for the purposes of determining recoverable profits in a subsequent short-swing should be the cash paid for it, plus the market value of the option on the date of exercise, or, in other words, the stock's market price at that date.

At present, however, computation of recoverable profits in transactions in which the purchase of stock is pursuant to the exercise of an option which has been held for more than six months may be governed by SEC rule $16 \mathrm{~b}-6$. .4 $^{4}$ Under this rule, profits are measured by subtracting from the proceeds of the sale the lowest market price of the stock within a period of six months before or after the sale. If applied to the hypothetical transaction just outlined, the rule would allow recovery of the difference between thirty dollars and the stock's lowest market price attained in the year beginning March 1, a figure no larger than and probably smaller than twenty dollars; the rule would therefore allow recovery of long-swing profits. The only reported case in which rule $16 \mathrm{~b}-6$ has been applied is Blau v. Hodgkinson, decided by the Southern District of New York. ${ }^{45}$ There, an insider who had made a short-swing sale of stack: acquired by exercising warrants he had held for nearly five years settled with his corporation by surrendering profits of 890 dollars, computed by subtracting the value of the warrants on the exercise date plus warrant price, from the proceeds of the sale. The plaintiff contended that profits must be computed by subtracting exercise price from sale price, making the recoverable profits 9,856 dollars. In an amicus curiae brief, the SEC urged retroactive application of rule $16 \mathrm{~b}-6$, under which recoverable profits were 1,820 dollars. The court's adoption of the rule may have been motivated by a desire to reach what it

44. 17 C.F.R. \$ 240.16b-6 (Supp. 1959):

(a) To the extent specified in paragraph (b) of this section the Commission hereby exempts as not comprehended within the purposes of section $16(b)$ of the act any transaction or transactions involving the purchase and sale or sale and purchase of any equity security where such purchase is pursuant to the exercise of an option or similar right either (1) acquired more than six months before its exercise, or (2) acquired pursuant to the terms of an employment contract entered into more than six months before its exercise.

(b) In respect of transactions specified in paragraph (a) of this section the profits inuring to the issuer shall not exceed the difference between the proceeds of sale and the lowest market price of any security of the same class within six months before or after the date of sale. Nothing in this section shall be deemed to enlarge the amount of profit which would inure to the issuer in the absence of the section.

....

45. 100 F. Supp. 361 (S.D.N.Y. 1951). 
felt was an equitable result. But its rejection of the defendant's contention that the settlement was a bar to the action was justified on the ground that the settlement had not been made in accordance with the method of profit computation "defined by ... [ [the] appellate court" 46 of its circuit. Furthermore, the count must have believed that the plaintiff's proposed measure of recovery would have been correct in the absence of $16 \mathrm{~b}-6$ since the rule by its terms is not supposed to increase the amount of profit otherwise recoverable.

But excluding from recovery profits resulting from long-term increment in a call's value is by no means foreclosed even in the Second Circuit. The Hodgkinson court cited no authority in support of its statement that rules of profit computation "defined by ... . [its] appellate court" made the defendant's settlement inadequate. Indeed, had the court followed the decision of its court of appeals in Park $\mathcal{E}$ Tilford, Inc. $v$. Shulte, ${ }^{47}$ the Hodgkinson settlement should have been held proper, assuming that the parties had correctly calculated the market value of the warrants. Park \& Tilford involved the conversion of preferred stock to common stock, with a subsequent sale of the common within six months. There the court held that the purchase price of the common was the market value of the preferred on the date of conversion. Although no money was exchanged for the common in Park \& Tilford, this factor does not support the implicit holding of the Hodgkinson case that when cash is paid in the exercise transaction, only the cash is relevant in determining the basis of the acquired stock. Rather, since the exercise of the warrants in Hodgkinson was analogous to the Park \& Tilford conversion transaction, the court should have allowed the market value of the warrants to be considered in computing profits. And, if calls are equity securities, the Securities Exchange Act indicates no reason why they also should not be treated similarly to the preferred stock in Park \& Tilford. ${ }^{48}$

46. Id. at 371 .

47. 160 F.2d 984 (2d Cir.), cert. denied, 332 U.S. 761 (1947).

48. But cf. Steinberg v. Sharpe, 95 F. Supp. 32 (S.D.N.Y. 1950), aff'd per ctriam, 190 F.2d 82 (2d Cir. 1951). In Steinberg, defendants resold stock within six months of its acquisition pursuant to employee "incentive" options. The options had been excrcised more than six months after their acquisition; in fact, the right to exercise did not accrue until one year after they were acquired. 'The court explicitly rejected the defendants' contention that the cost basis of the stock should include the worth of the option on the day it was exercised, on the grounds that defendants in similar situations could evade $\$ 16$ merely by holding aptions for a long time and then reselling the stock acquired while the market was still high. On the other hand, since the court recognized that some of the value of the option "represented long-term increment" in the value of the underlying stock, the cost-basis was held to include the worth of the option on the day the right to exercise accried, as this would "represent the amount of compensation which the corporation paid the defendant pursuant to its agreement. . ." 95 F. Supp. at 34 . While the method of computation chosen in this case may have a deterrent effect upon speculation in employment options, it allows the amount of recovery to turn solely on the fortuitous movement of the market between issuance of the option and accrual date. And even if it is proper to assume that the corporation intended any market rise to be "com- 
Admittedly, adoption of the computation method here advocated would nullify rule 16b-6's application to transactions involving the exercise of calls. But nullification in this manner would be both desirable and proper, as the rule is defective in several respects. First, it utilizes the six-month holding period as an arbitrary aid to measurement of profits, whereas under the statute the purpose of the six-month time limitation is to define the speculative transactions which lead to liability. Second, $16 \mathrm{~b}-6$ permits profits to be computed on the basis of market fluctuations taking place after, as well as before, the sale. ${ }^{00}$ The SEC has indicated that this aspect of the rule was intended to eliminate the possibility that insiders would use their inside information to predict a market decline, selling when the market was at its crest.00 Thus, not only is the amount of recovery fortuitous, but the reason for allowing it goes beyond the thrust of the statute, which is obviously not designed to penalize selling at the crest unless such selling is coupled with a subsequent repurchase. Finally, $16 \mathrm{~b}-6$ may be beyond the Commission's rulemaking power. Section 16(b) permits the Commission to exempt "transactions," but says nothing as to its power to limit or increase recoverable profits once liability has been found. ${ }^{\text {.1 }}$

When the initial step in a short-swing transaction is the exercise of a put which has been held for more than six months, courts should recognize that by exercising the put the insider has given up an option with independent market value. As this value is attributable to a long-swing decline in the market price of the stock subject to the option, it should not be included in computing the profits recoverable should the insider repurchase the stock within six months. This result can be accomplished by subtracting the market value of the put on the exercise date from the cash profits realized on the shortswing transaction. Since 16b-6 does not apply to options to sell, a court should have no difficulty adopting this approach, which is identical to that proposed for calls.

An objection to limiting the amount of profit recoverable on a short-swing merely because the put or call exercised has been held more than six months is that this approach permits the insider to assume a fixed market position from which to watch the market, committing himself to a substantial investment in the stock of his corporation—or reducing his equity ownership-only

pensation," insiders who anticipate a future market rise, and who presumably control their own corporations, might evade $\$ 16$ by issuing options with a distant accrual date. Finally, the court, in allowing the worth of the options at accrual to be included in the cost-basis, recognized the propriety of allowing some long-term increment to be retained. Steinberg's allowance of recovery of other long-term increment cannot, therefore, be controlling as to puts and calls, whose accrual date is coincident with acquisition date; to compute basis according to accrual date would be to deny completely any long-term profit upon exercise.

49. See text of rule $16 \mathrm{~b}-6$, sipra note 44 .

50. SEC Exch. Act Release No. 4509, Oct. 30, 1950.

51. See Hardee, supra note 35, at 1006; of. Rattner v. Lehman, 193 F.2d 564, 566 (2d Cir. 1952). 
after the market has swung in his favor. ${ }^{52}$ Furthermore, as the SEC pointed out in the release accompanying $16 \mathrm{~b}-6$, options were a concomitant of the market manipulations of insider stock pools. ${ }^{53}$ Thus it may be felt that options present such a danger of insider abuse that an arbitrary deterrent such as rule $16 \mathrm{~b}-6$ is justified. But, as has been pointed out, transfers of unexercised puts and calls probably require no greater surveillance than transfer of other securities. ${ }^{54}$ And the history of $16 \mathrm{~b}-6$ indicates that the rule in its present form was an attempt to leave to the courts the problems created by option exercise. In a statement accompanying a proposed earlier version of $16 \mathrm{~b}-6$, the Commission stated flatly that the correct purchase price of a security acquired through option exercise should be only option cost plus option price.65 The original rule was then proposed in order to temper liability, by requiring recovery to be computed by the method now provided in $16 \mathrm{~b}-6$. The rule provided that recoverable profit was not to exceed the difference between sale price and "the sum of the cost of the option and the exercise price." After receiving public comment on the proposed rule, however, the Commission withdrew it, noting that so much uncertainty appeared to exist as to the correct method of computing the cost of stock acquired through exercise of options that no rule should issue prior to judicial determination of the matter. ${ }^{57}$ No further judicial determination took place prior to the promulgation of the present $16 \mathrm{~b}-6$. The new rule replaced the previous maximum recovery with the ambiguous phrase, "nothing in this section shall be deemed to enlarge the amount of profit which would inure to the issuer in the absence of this section." 58 In the accompanying release, the Commission conceded that the method of computing cost-basis was not entirely settled, and that the new rule left the courts room to minimize recoverable profits by construing the section 16(b) phrase "profits realized by" to exclude all long-term increment in option value. ${ }^{59}$ By thus giving the courts what amounts to a choice between computing recoverable profits under the rule or under an analogy to Park \& Tilford, the Commission sidestepped the issue of whether transferrable options actually create such dangers of market abuse that special treatment is warranted. Unless and until a contrary solution, which will cover both exercise

52. See Perlman v. Timberlake, 172 F. Supp. 246, 256 (S.D.N.Y. 1959); Stcinbcrg v. Sharpe, 95 F. Supp. 32, 33-34 (S.D.N.Y. 1950), aff'd per curiam, 190 F.2d 82 (2d Cir. 1951).

53. See SEC Exch. Act Release No. 4509, Oct. 30, 1950; SEC Exch. Act Relense No. 4045, Feb. 6, 1948.

54. See text at notes 29-32 supra.

55. SEC Sec. Act Release No. 4045, Feb. 6, 1948. The Commission stated that recovery of profits so computed was "not only 'comprehended within the purpose of' Section 16(b), but essential to prevent its evasion in view of the historic use of the option device in connection with manipulations."

56. Ibid.

57. SEC Exch. Act Release No. 4145, Aug. 6, 1948.

58. 17 C.F.R. \& 240.16b-6 (Supp. 1959).

59. SEC Exch. Act Release No. 4045, Feb. 6, 1948. 
and sale of puts and calls, is reached by Congress, application of any rule which allows recovery of a long-term increment in the value of an option, the exercise of which begins a short-swing transaction in stock, will penalize form rather than substance, and must be based not on the presumptions of the statute but upon the "possibility of [insider] abuse as supposed and conjectured by judges."

\section{Exercising or Selling a Put or Call as Delayed Stcp Two in a Short-Swing Transaction in Stock: "Profit-Freczing" Transactions}

Different considerations apply when an option is used as a hedge to protect short-swing "paper" profits from later market fluctuations. These "profit-freezing" transactions are characterized by the purchase or sale of stock and the acquisition of a put or call within six months, followed by actual realization of the ensuing profit through exercise or disposition of the option more than six months after the transaction is begun. Assume, for example, that an insider, expecting a short-term rise, purchases stock at forty dollars. Before the six-month holding period expires the market rises to ninety dollars. In an effort to avoid section 16(b) liability without exposing himself to the risk that the market will drop before the shares can be sold, the insider may purchase a put, entitling him to sell his shares at ninety dollars any time during the life of the put. ${ }^{61}$ Should the market then drop, the insider will simply wait until the six-month holding period expires and then exercise the put, selling at ninety dollars the stock he bought at forty dollars. Such a maneuver may evade 16(b) unless it is possible to treat the acquisition of the put as a sale of stock in order to match it against the original purchase for purposes of finding liability. Three other option transactions present the same problem. Stock may be sold at a high price, and a call acquired after the market drops. Or the option may be acquired before a purchase or sale. When the market is rising, acquisition of a call before a sale of stock already owned ensures ability to repurchase at a lower price. In a falling market, acquisition of a put may be followed by the purchase of stock. In each of the four transactions discussed, the trader has guaranteed himself a profit of no less than the difference between his purchase or sale price and the exercise price of the option, less the cost of the option. By delaying exercise of the option, he has only delayed realization of this profit.

60. The quoted language is that of Judge Lumbard's criticism of the majority's disapproval of SEC rule 16b-3, in his dissenting opinion on petition for rehesring in Greene v. Dietz, 247 F.2d 689, 697 (2d Cir. 1957).

61. See Put and Cali Brokers and Dealers Ass'x, Inc, Put Option and Cais OptIon Contracts 8 (3d ed. 1958); Finer 46-47. Stop-loss orders as well as puts can be used to protect profits, but they offer less opportunity to evade $\$ 16(b)$. Use of a put enables a postponement of profit realization that is impossible with a stop-loss order, which operates automatically when a predetermined market price has been reached. With puts, the selling price is guaranteed for the life of the option, while a stop-loss order ensures only the best price obtainable after the predetermined "stop" price has been reached. See FIIIR 52 . 
Thus, acquisition of an option can put an insider in a position to complete a purchase or sale at prices which prevailed during a six-month period in which he is presumed to have had an opportunity to take advantage of inside information. In order to treat these transactions properly, courts must regard acquisition of the option as equivalent to a purchase or sale in order to match it against the complementary purchase or sale of stock. The initial problem, therefore, is the verbal one of fitting acquisition of an option to purchase or to sell into statutory descriptions of "purchase" and "sale." Section 3(a) (13) defines "buy" and "purchase" to "include any contract to buy, purchase or otherwise acquire";02 section 3(a)(14) defines "sale" similarly. ${ }^{03}$ Puts and calls are popularly referred to as "contracts," but this appellation is of no relevance in determining their status under section $3(\mathrm{a})$. They may be described as unilateral contracts in which the premium is paid in consideration for the option-writer's promise to buy or sell stock at a certain price. ${ }^{\text {of }}$ But such an option contract is not a contract to buy or sell stock, but rather one to make an offer to buy or sell stock at a particular price irrevocable. ${ }^{00}$ Thus, as a matter of general contract law outside the framework and policies of the Securities Exchange Act, a put or a call would be classified as an irrevocable offer to enter a unilateral contract, which would not ripen into a "contract" until accepted through exercise. ${ }^{67}$ But, because of the irrevocable nature of the option-writer's promise, the principal functional distinction between an offer for a unilateral contract and such a contract itself-the promisor is bound in the latter, but not in the former-is here obliterated. Arguably, however, Congress' use of the term "contract" referred only to contracts in which both buyer and seller are bound. Indeed, in Stella v. Graham-Paige Motors Corp.," the court stated broadly that "until both parties are bound there is no 'purchase' or 'sale' under the act." 60 If this definition of purchase or sale governs, the transactions under discussion will be exempt from $16(\mathrm{~b})$ because the option-holder is free not to exercise. This reading of the statute would be undesirable in the context of puts and calls, since all a speculating insider needs to profit from inside information is "firm assurance that a fixed quantity [of stock] can be acquired or disposed of at a fixed price."70 It should make no

62. 48 Stat. 884 (1934), 15 U.S.C. $\$ 78 c$ (a) (13) (1958).

63. 48 Stat. 884 (1934), 15 U.S.C. \& 78c(a) (14) (1958).

64. E.g., FILER 18-19.

65. See Restatement, Contracts $§ 12$ (1932) (unilateral contract defined).

66. See $i d . \S 46$.

67. See id. § 52; Shaw v. Dreyfus, 172 F.2d 140, 142 (2d Cir. 1949) (warrants "not themselves a contract to acquire shares . . . [but] mere offers by the corporation").

68. 132 F. Supp. 100 (S.D.N.Y. 1955), remanded for findings, 232 F.2d 299 (2d Cir.), cert. denied, 352 U.S. 831 (1956). The case was remanded for a finding on the question of profits, 232 F.2d at 302, but the court of appeals agreed with the district court's standard for determining a purchase and sale, $i d$. at 301 .

69. 132 F. Supp. at 104.

70. Blau v. Ogsbury, 210 F.2d 426, 427 (2d Cir. 1954) ; cf. Falco v. Donner Foundation, 208 F.2d 600, 604 (2d Cir. 1953) (purchase and sale in arbitrage transactions under $\$ 16(d))$. 
difference whether he enters into a contract binding on both parties or acquires an option under which the obligations of the option writer are fixed. In Stella the party with whom the insider was dealing retained power to withdraw from the contract until the date when both became bound." Thus Stella is readily distinguishable from the put and call situation in which only the insider may withdraw. In any event, to rule that acquisition of a put or call is not a sale or purchase simply because it does not seem to be a "contract" because the insider is not bound, or, indeed, has not "accepted" through performance is to ignore both the broad purposes of section $16(\mathrm{~b})$ and the language of section 3 (a). According to 3(a)'s preamble, its definitions apply only "unless the context otherwise requires." 72 In the profit-freezing transactions here under discussion, short-swing profits arise between sale or purchase of stock and acquisition of an option, and only realization is postponed until exercise. The context of $16(\mathrm{~b})$ would therefore require that the acquisition of an option be deemed a purchase or sale when necessary to prevent the retention of shortswing profits.

Regarding the acquisition of an option as a purchase or sale will enable courts to match sales or purchases of stock against acquisitions occurring within less than six months. Section 16(b) liability, however, cannot attach until profits are "realized." Thus it becomes necessary to determine when and under what circumstances the insider may realize profit and to determine principles for the computation of recoverable profits. Assume, for example, that an insider sells stock at ninety dollars and within six months acquires a call entitling him to purchase stock at forty dollars. Should the market continue to drop, the insider will allow his call to expire and purchase stock on the market. Here no profits would be recoverable since the profits realized are not attributable to the sale of stock and acquisition of a call on a short-swing. If the market rises to seventy dollars during the life of the call and after the expiration of the six-month period, however, the insider will either exercise his call or sell it unexercised. If he exercises, short-swing profits have clearly been "realized." He has returned to his original equity" position with more cash than he would have had if he had carried out a longswing transaction in the stock alone. Sale of the option unexercised should likewise be considered a "realization" of profit. Although sale of the call does not in itself return the insider to his original equity position, it leaves him with proceeds which he could use to buy stock, thus accomplishing the same result as he could by exercise. Arguably, liability could not attach until stock was purchased, and then only if the purchase occurred so close to the sale of

71. 132 F. Supp. at 105. Graham-Paige Motors Corp. sold its assets to Kaiser-Frazer for a sufficient amount of Kaiser-Frazer stock to make it a $10 \%$ beneficial holder and an insider under $\$ 16(\mathrm{a})$. The court held the "purchase" of stock for $\S 16(\mathrm{~b})$ purposes did not occur prior to the closing on Feb. 10, 1947, because prior to that time neither party was bound. Graham-Paige could have withdrawn by failing to secure a bank loan, and Kaiser-Frazer could have withdrawn by refusing to guarantee the loan.

72. 48 Stat. 882 (1934), 15 U.S.C. $\$ 78 \mathrm{c}(\mathrm{a})$ (1958). 
the option for the transaction to be regarded as equivalent to option exercise. According to this argument, the acquisition of a call would be a purchase only when, as in traditional purchases, the insider is in the same equity position with respect to the repurchased shares at the close of the transaction as at the beginning; hence, profits from the sale of the option would be no more recoverable than are profits from a long-swing transaction in the stock at market price after the option has been allowed to expire. Such an approach, however, would unnecessarily complicate the judicial administration of $16(\mathrm{~b})$ in cases involving puts and calls and might encourage their use to protect short-swing profits. Accordingly, it is recommended that proceeds from the sale of an unexercised option be regarded as profits attributable to a short-swing transaction-purchase or sale of stock plus acquisition of an option within six months-and therefore as profits recoverable under section 16(b).

The proper measure of recovery to apply to this short-swing transaction would be the difference between option price (in the hypothetical, forty dollars) and market price on exercise date (seventy dollars) -in other words, the option's value at exercise date-whether profits are realized through exercise or sale of the option. Recovery here is designed to eliminate any advantage which the insider gained by acquiring an option on the short-swing. 'Option value on exercise date will depend on market movements which would have been unfavorable to the insider had he not acquired the option. Thus, in the hypothetical situation, the value of the call (thirty) is attributable to the market rise to seventy. Recovery of the value of the option eliminates any advantage attributable to the option and puts the insider in the same position he would have occupied had he purchased stock at the market price on exercise date.

When, in a profit-freezing transaction, more than six months passes between option acquisition and disposition or exercise, however, recovery of the value of an option may at first seem contrary to the previous suggestion that the insider be allowed to retain profits attributable to long-swing increments in the worth of options. ${ }^{73}$ But both principles can be applied consistently with each other and with the principles of $16(\mathrm{~b})$. When it was urged that an insider be credited with option value on exercise date, it was postulated that he had held the option for more than six months prior to exercise and sale or repurchase of stock. In such a case, inside information is of no more value to him than if he had simply purchased stock on the date he acquired the option. In the transactions now under discussion, the option has been used in such a way that inside information could have played a part in his maneuvers; the insider has placed himself in a position to take advantage of market prices prevailing less than six months after the original sale or purchase, and the length of time he holds the option is irrelevant.

Thus the basic principle applicable to transactions in which acquisition of a call is combined within six months with sales of the underlying stock-or

73. See text at notes $43-60$ sipra. 
acquisition of a put with purchases-is that when profits are realized through sale or exercise of the option, the difference between option price and market price on exercise or option sale date (the value of the option) is recoverable under $16(\mathrm{~b}) .^{74}$ This principle is subject to one modification. In some cases, the difference between option price and market price on exercise date will exceed the amount of frozen paper profits. In the hypothetical case previously sketched, in which the insider sold stock at ninety dollars and acquired a call enabling him to purchase at forty dollars, assume that the market rose to a hundred dollars, instead of seventy dollars, after acquisition of the call. Applying the general rule just stated, recovery would be sixty dollars, the difference between option price and market price at exercise date. But absent the option, the insider would have had a long-swing loss of ten; the option has not only frozen profits but prevented this loss. Since $16(\mathrm{~b})$ evinces no policy against the use of options to prevent loss, recovery in this type of case should be limited to the profits attributable to the short-swing transaction, here fifty dollars.

Whether the option's value should be the maximum recovery depends upon the length of time between the two transactions in stock involved. Since the purpose of recovery is prevention of the use of options to protect short-swing profits, recovery of more than the option value is unnecessary when exercise date and the initial transaction in stock are more than six months apart. The hypothetical previously described ${ }^{75}$ will serve as an illustration. It might seem that since the insider sold stock at ninety dollars and repurchased it at forty dollars through exercise of the call, recoverable profits should always be fifty dollars. But this approach is unduly harsh, since, according to the hypothetical's original terms, the insider could have sold stock at ninety dollars and bought it at seventy dollars without using the option, and without being subjected to $16(\mathrm{~b})$ liability. Furthermore, profits of fifty dollars would not be recoverable when the option was sold instead of exercised, unless the courts wished to undertake the difficult problem of determining when a purchase of stock occurred so close to the sale of a call that the two events together could be treated as an exercise of the call. When the sale and purchase of stock are more than six months apart, recovery of the value of the option provides a simple, consistent, and effective means of deterring the use of options to protect short-swing profits.

74. This principle is also applicable to puts. Suppose that a put is acquired at $\$ 90$, stock purchased at $\$ 40$ within six months, and the put exercised after the six-month period has expired when the market is $\$ 70$. Here the value of the put is $\$ 20$, the difference botween option price (90) and market price on date of exercise (70). It is true that total profit "frozen" is $\$ 50$, the difference between option price $(90)$ and purchase price of stock (40). But the insider could have purchased stock at $\$ 40$ and sold it at $\$ 70$ instead of exercising his put, and he could have retained the $\$ 30$ profit without liability. Thus, only the additional $\$ 20$ (option value) can be considered advantage derived from shortswing activity, and is all that should be recovered.

75. Text preceding note 73 supra. 
But profit-freezing transactions may be posited in which the purchase and sale of stock occur within six months of each other, and here recovery should be a figure greater than the option's value. Assume, for example, that a call exercisable at forty dollars is acquired, followed within six months by the sale of stock at ninety dollars, and, at a time within six months of the sale but more than six months from the call's acquisition, by exercise when the market price of the stock is seventy dollars. It has already been demonstrated that it would be incorrect to credit the insider with the long-swing appreciation of his option, making recoverable profits only twenty dollars. Likewise it would be incorrect to recover only the value of the option, here thirty dollars, which would leave the insider with profits of twenty dollars on a short-swing sale of stock at ninety dollars and purchase of stock through the call's exercise at forty dollars. Thus recoverable profits must be fifty dollars. The hypothetical transaction may be looked upon as two short-swings: (1) the acquisition of a call and the sale of stock; and (2) the sale of stock and the exercise of the option within a second six-month period. Profits on the first transaction-the option's value at the date of the final transaction (here thirty dollars)-are recoverable when realized through sale or exercise of the option whenever that occurs; profits on the second-the difference between purchase price of the stock and sale price of the stock (here twenty dollars) -are realized and recoverable if sale-purchase of stock on a short-swing in fact occurs. ${ }^{78}$ Although the sale of stock is common to both transactions, there should be no objection to its beings used twice, ${ }^{77}$ and a recovery of fifty dollars would eliminate all possibilities of profiting from inside information.

In sum, profit-freezing transactions will be adequately policed by recovery of option value-the difference between option price and market price of stock

76. Instead of the hypothetical case discussed in the text, assume that the call is sold for $\$ 30$, five months and twenty-nine days after the sale of stock, but that stock is not purchased at $\$ 70$ until six months and one day after the sale. The profit of $\$ 20$ on the sale and purchase of stock is by definition a nonrecoverable long-swing profit. Thus, it need not be added to the proceeds from sale of the option in order to eliminate all short-swing profits.

77. A dictum in Gratz v. Claughton, 187 F.2d 46, 52 (2d Cir.), cert. denied, 341 U.S. 920 (1951), states that "no transaction can figure in more than one equation," that is, once sale of stock cannot be matched against each of two purchases of stock. To do so would give double recovery in a series of transactions involving only stock. Thus, the dictum is correct on the facts of the Gratz case. This language should not be extended to cover the transaction set out in text, however. Here it is proper to match the sale both against acquisition of the call in order to recover the value of the option and against exercise in order to recover the difference between market price on exercise date and sale price. There is no double recovery; rather the insider is obliged to disgorge only the full amount of profits he has actually realized.

If the option is sold rather than exercised, only the value of the option-here $\$ 30$ would be recoverable, since that would be the measure of profits realized on the shortswing transaction matching the call's acquisition with sale of the stock. But if after the call were transferred, stock were purchased within six months of the sale of stock, the sale could similarly be used twice so that this short-swing transaction in stock alone would not go unrecovered. 
on exercise date-provided that this difference does not exceed the amount of profit frozen between the sale or purchase of stock and the acquisition of the option, plus any profits on an actual short-swing sale and purchase of stock. But SEC rule 16b-6, which governs the purchase of stock "pursuant to the exercise of an option ... acquired more than six months before its exercise,"78 is arguably applicable to profit-freezing transactions in which a call is held for six months before exercise. Rule $16 \mathrm{~b}-6$ measures recovery by the difference between the proceeds of sale of stock and the lowest market price within six months before or after the date of sale. Since for practical purposes call price equals market price of the stock on the date the call is acquired, and since acquisition date in profit-freezing transactions is by definition within six months of a sale of stock, rule $16 \mathrm{~b}-6$ would lead to the recovery of the full differential between option price and sale price. But, aside from the previously delineated defects of $16 \mathrm{~b}-6,{ }^{79}$ the rule should not prevent the imposition of the smaller recovery represented by option value when appropriate. By its own terms $16 \mathrm{~b}-6$ is designed to limit rather than to increase profits recoverable under $16(\mathrm{~b})$, leaving the courts free to impose a lesser measure of recovery. ${ }^{80}$ Furthermore, the Commission release issued when the rule was promulgated indicates that the Commission gave little or no consideration to transactions in which options are used to protect short-swing profits. ${ }^{81}$ And since $16 \mathrm{~b}-6$ is inapplicable to puts and to sales of unexercised options, the rule may be disregarded when either puts or calls are used in a profit-freezing context.

Complicating considerations arise in transactions involving either two sales or two purchases of stock-one sale or purchase occurring within six months of the acquisition of an option and the other within six months of its exercise. Assume a sale of stock at ninety dollars, followed within six months by acquisition of a call exercisable at forty dollars. More than six months after the initial sale, the call is exercised when market price is seventy dollars, and, within six months of exercise, the stock is resold at 105 dollars. Here the insider has actually acquired stock only once-on exercise date- although his power to buy at option price became fixed when the call was acquired. Thus it might be argued that either acquisition date or exercise date, but not both, could be considered a purchase. This transaction could then be analyzed either as profit freezing-sale of stock accompanied within six months by the acquisition of a call -or as a transaction in which exercise is step one in a short-swing in stock. If the former, purchase would be deemed to have taken place on acquisition date, and recovery would be thirty dollars, the value of the option. If the latter, purchase would be deemed to have taken place on exercise date and recovery under the previously suggested analogy to the Park

78. 17 C.F.R. $\S 240.16 \mathrm{~b}-6$ (Supp. 1959). Pertinent portions of the rule are quoted in note 44 sitpra.

79. See text at notes 49-51 sipra.

80. See text of rule supra note 44 ("nothing in this [rule] . . shall be deemed to enlarge the amount of profit which would inure to the corporation in the absence of the ... [rule]").

81. See SEC Sec. Act Release No. 4509, Oct. 30, 1950. 
\& Tilford case would be thirty-five dollars. ${ }^{82} \mathrm{~A}$ court would probably pick the second alternative, since it gives the larger recovery. ${ }^{83}$ If both acquisition and exercise can be regarded as purchases for 16(b) purposes, however, profits attributable to both the profit-freezing and the exercise transactions will be recoverable, giving a total of sixty-five dollars. Suppose the insider had sold the option on exercise date, receiving proceeds of thirty dollars. These proceeds would be recoverable as profits realized on the short-swing profit-freezing transaction. A purchase of stock at seventy dollars followed two months later by sale of stock at 105 dollars would produce recoverable profits of thirty-five dollars. Thus, if the transaction took this form, recoverable profits would clearly be sixty-five dollars. Since exercise of a call may be regarded as equivalent to a sale of the call accompanied by the purchase of stock, the fact that the option is exercised should not produce a different result. Recovery of the full profit is in accordance with the scheme of 16(b). Acquisition of the option froze profits on a speculation conclusively presumed to have been an abuse of inside information. Assuming the option was terminable, exercise gave the insider a new opportunity to misuse inside information to take advantage of the short-swing between exercise and sale.

Profit-freezing transactions need not be confined to the forms discussed here. For example, acquisition of a call at a low price might be followed by acquisition of a put at a high price. Or a sale of common stock might be followed by the purchase of convertible preferred. Such cases may be easily solved by applying the basic principle underlying profit-freezing liability-that purchases and sales of different classes of equity securities may be matched when one class is convertible into the other or where both classes are convertible into the same class of equity security ${ }^{84}$ Although difference in market prices may make computation of recoverable profits difficult, failure to recognize this principle would make for easy evasion of $16(\mathrm{~b})$. For by acquiring a convertible security as part of a short-swing, the insider obtains a potential advantage he would not have had if he had simply carried out a long-swing transaction in securities of the same type. Possibly this advantage will not be turned to profit since the insider may allow the conversion feature of the convertible security to expire. When he converts or sells the conversion security while it is still convertible, however, any advantage secured as the result of the short-swing transaction should constitute recoverable profit.

\section{Other Problems Involving Puts and Calls - Acquisition of Options as a "Change in Beneficial Ozenership"}

If acquisition of a call is treated as a purchase of stock and acquisition of a put as a sale for purposes of $16(\mathrm{~b})$, it may be argued that such purchases

82. See text at notes $47-48$ supra.

83. See Gratz v. Claughton, 187 F.2d 46, 51-52 (2d Cir.), cert. denied, 341 U.S. 920 (1951).

84. Compare Comment, 59 Y ALE L.J. 510, 533 (1950). 
and sales constitute changes in beneficial ownership which must be taken into account in determining whether or not a shareholder is a ten per cent beneficial owner and hence an insider under 16(a). Some support for this position may be derived from SEC rule 16a-1(h) under which acquisition of a put or call is "deemed to be such a change in beneficial ownership" of the underlying securities as to require reporting. ${ }^{85}$ The classification of ten per cent beneficial owners as insiders, however, is based on a conclusive presumption that the owner of ten per cent of any one class of a corporation's equity securities has such control over corporate policies and access to inside information that speculative abuses are possible. Obviously, such access and control are not diminished by the acquisition of puts. The ownership of a call, on the other hand, resembles beneficial ownership of stock in some respects. For example, any dividends declared during the life of the call will be credited against exercise price. ${ }^{86}$ But the right to dividends is conditioned on exercise and is of little importance for section 16 purposes. More relevant is the possibility that the owner of calls, having the power at any time to obtain control of stock, might reasonably be supposed to have more access to inside information and to exercise a greater measure of control than his actual stocliholdings might indicate. But to elevate this possibility to the status of a conclusive presumption by holding, for example, that a nine per cent owner who acquires calls on an additional one per cent thereby becomes an insider seems somewhat far fetched. Under existing law, "beneficial ownership" is held to remain unchanged until there is a "firm commitment" to purchase or sell securities," and acquisition of a call gives rise to no such commitment.

85. For the purposes of this section the acquisition or disposition of any transferable option, put, call, spread, or straddle shall be deemed such a change in the beneficinl ownership of the security to which such privilege relates as to require the filing of a report reflecting the acquisition or disposition of such privilege. Nothing in this paragraph, however, shall exempt any person from filing the reports required upen the exercise of such option, put, call, spread, or straddle.

17 C.F.R. \& 240.16a-1(h) (Supp. 1959).

86. See FILER 75-76.

87. See Stella v. Graham-Paige Motors Corp., 232 F.2d 299, 301 (2d Cir. 1956), citing with approval SEC Sec. Exch. Act Release No. 116, MFarch 9, 1935, 11 Fed. Reg. 10968 (1946):

In my opinion an officer, director or stockholder is to be deemed to have acquired beneficial ownership of a security at the time when he takes a firm commitment for the purchase thereof, and to divest himself of such owmership at the time when he takes a firm commitment for the sale thereof. If it is necessary that certain conditions be satisfied prior to the consummation of the purchase or sale, and if it is uncertain whether such conditions will be satisfied, then it would appear that the officer, director, or stockholder would not acquire beneficial ownership, or divest himself thereof, until such time as such conditions are satisfied and the undertaking to purchase or sell becomes a firm commitment.

See also Loss $584-86$. 


\section{Puts as Short Sales}

Not to be overlooked in connection with puts is section $16(\mathrm{c}), 88$ which prohibits "short sales" and "sales against the box" 80 by insiders. If the acquisition of a put is a "sale" for 16(c) purposes, it would be unlawful for an insider who owned no stock in his corporation to acquire a put because 16 (c) (1) forbids short sales-selling "any equity security of such issuer ... if the person selling the security or his principal . . . does not own the security sold." If the insider already owned the stock on which he purchased his put, application of the proposed definition of "sale" would require any put acquired to be exercised so that the stock could be delivered "against stuch sale within twenty days thereafter" as required by $16(\mathrm{c})(2)$ 's prohibition of sales against the box. Whether such a position should be adopted depends on the purposes of $16(\mathrm{c})$. Arguably, the section indicates congressional intent that no insider be allowed to profit from a drop in the value of his corporation's securities, thus bringing puts within the spirit of the section. ${ }^{00}$

But other considerations make it undesirable to hold a put a "sale" for purposes of section $16(\mathrm{c})$. Legislative history indicates that Congress felt short sales should be regulated because market declines are accelerated when short-

88. 48 Stat. 896 (1934), 15 U.S.C. $\$ 78 p(c)$ (1958):

It shall be unlawful for any such beneficial owner, director, or officer, dircetly or indirectly, to sell any equity security of such issuer (other than an excmpted security), if the person selling the security or his principal (1) does not own the security sold, or (2) if owning the security, does not deliver it against such sale within twenty days thereafter, or does not within five days after such sale deposit it in the mails or other usual channels of transportation; but no person shall be deemed to have violated this subsection if he proves that notwithstanding the exercise of good faith he was unable to make such delivery or deposit within sttch time, or that to do so would cause undue inconvenience or expense.

89. In "sales against the box" the

seller owns and possesses stock which he can deliver but which for some renson he prefers not to deliver. This is a device which can be employed by corporate officials and insiders who desire to sell their corporation's stock short without disclosing such short selling. Like the ordinary short seller, he borrows stock for the purpose of making delivery. It is contended by stock-exchange authorities that a sale "against the box" is not a short sale, since the customer need not buy the stock back but may make delivery from the securities in his box. It is plain, however, that where a person initially makes a sale "against the box" but subsecquently changes his mind, there is nothing to prevent him from covering in the open market. In such case he is indistinguishable from any other short seller.

S. REP. No. 1455, 73d Cong., 2d Sess. 52 (1934); see Bakal, Playboy Plays the Marlict, Playboy, Oct. 1959, p. 68, at 109.

90. Section 10(a) of the Securities Exchange Act places short sales generally under the regulatory power of the SEC. 48 Stat. 891 (1934), 15 U.S.C. \& 78j(a) (1958). Rule 10a-1, 17 C.F.R. $\S 240.10 \mathrm{a}-1$ (1949), regulates prices at which short sales can be made, and requires "short" and "long" sales to be identified. Rule 10a-2, 17 C.F.R. $\$ 240.10 \mathrm{a}-2$ (1949), provides penalties for brokers who assist in carrying out a sale violating rule 10a-1. Short sales by noninsiders complying with these rules are permitted. 
sellers contribute their stock sales to an already overburdened market. ${ }^{21}$ In prohibiting insider short-sales, Congress may also have been concerned with the psychological effect of insider sales in a falling market. ${ }^{92}$ Acquisition of a put does not involve an actual sale of stock on the market and therefore does not directly accelerate market declines. When the insider acquires a put without owning the stock, puts may actually bolster declining prices somewhat, since the option holder must buy stock in order to exercise the put. Unlike ordinary short-sellers who attempt to wait until the market has hit bottom before covering their short-sale, the holder of a put must make his purchase prior to expiration, even though the market may not have reached bottom of its downswing. ${ }^{93}$ Furthermore, it is doubtful if the acquisition of a put, even though publicized under 16(a), would have as great a psychological impact on the market as does an actual sale of stock. Finally, the use of puts in various legitimate "insurance" transactions " would no longer be possible if acquisition were to be deemed a sale under section $16(\mathrm{c})$. On balance, then, it seems that no compelling reason exists for construing "sale" as broadly in $16(\mathrm{c})$ as in $16(\mathrm{~b})$. Indeed, since violation of $16(\mathrm{c})$ may lead to criminal penalties, ${ }^{95}$ such a construction may violate due-process standards. Criminal statutes are ordinarily strictly construed and must apprise the offender of the exact nature of the violation..$^{98}$

\section{Insider Writing of Puts and Calls}

The "making" or "writing" of puts and calls may provide insiders with an opportunity to profit from inside information without incurring $16(\mathrm{~b})$ liability. Writers of puts and calls receive premiums from option buyers. If the put or call is allowed to lapse, this premium is retained by the writer. ${ }^{07}$ An insider with advance knowledge of a probable short-swing rise could write puts giving the holders the right to sell to him at the then market price. As the market rises, the puts will be permitted to expire and the insider-writer can pocket the premium. Although his profit will be less than if he had bought and sold stock or options to purchase, he will have avoided section 16. Even

91. See Loss 675.

92. Public knowledge of sales of large blocks of stock by insiders may have an adverse effect on the market. See, e.g., N.Y. Times, Feb. 16, 1960, p. 46, col. 1 (American Motors drops $9 \mathrm{~T} / 2$ points following announcement of large sale by corporation president George Romney).

93. According to one authority on puts and calls, the effect of option trading is to stabilize the market. See Frner 74-75.

94. "Profit-freezing" itself involves the use of puts and calls as "hedges" or "insurance." Hedging transactions would seem legitimate under $\$ 16(\mathrm{~b})$ if the "hedge" does not protect short-swing profits. For examples of hedging transactions, see FueR $46-48$.

95. Section 32, 48 Stat. 904 (1934), 15 U.S.C. $\$ 78$ ff (1958), provides for penalties up to $\$ 10,000$ or not more than 2 years imprisonment, or both. for willful violations of any provisions of the act making the violation "unlawful."

96. See Commissioner v. Acker, 361 U.S. 87, 91 (1959).

97. For a detailed discussion of option writing, see FILER 96-111. 
if the sale of a newly written put or call constitutes a "disposition" of the option so as to require reporting in compliance with $16 \mathrm{a}$ as interpreted in rulc $16 \mathrm{a}-1(\mathrm{~h}), 16 \mathrm{~b}$ liability will not follow for no purchase-sale combination has occurred. The possibility of exposure may well serve to deter insider option writing. Option writing is ordinarily carried on secretly, as the brokers who deal in puts and calls do not divulge the identity of the writers. ${ }^{88}$ In any event, it seems unlikely that insider option writing will become a widespread problem, since the writing of puts and calls primarily appeals to large investors seeking a steady return on their portfolios rather than to insiders making short-swing speculations. ${ }^{\text {go }}$

98. See LEFFLER 372.

99. See note 18 sipra. 